\title{
Histopathological spectrum of thyroid lesions
}

\author{
Ayesha Fatima, 1,", Rashmi A. Tolnur², B. V Patil ${ }^{3}$, V. D. Dombale ${ }^{4}$ \\ ${ }^{\mathbf{1}}$ Assistant Professor, ${ }^{2}$ Private Practice, ${ }^{3}$ Professor, ${ }^{4}$ Professor \& Head, Dept. of Pathology, ${ }^{1}$ Khaja Banda Nawaz Institute of \\ Medical Sciences, Karnataka, ${ }^{2,4}$ S Nijalingappa Medical College, Bagalkot, Karnataka, India
}

*Corresponding Author:

Email: ayesha.fatima1989@gmail.com

Received: $9^{\text {th }}$ July, 2016

Received: $25^{\text {th }}$ November, 2017

\begin{abstract}
Introduction: Thyroid lesions are fairly common \& have a wide spectrum of diseases ranging from functional, immune mediated to neoplastic lesions.

Objectives: 1) To study the occurrence of various lesions of the thyroid.

2) To study and correlate clinico-morphological features.

Results/ Observation: All thyroidectomy specimens were included in the study period of two years i.e, from January 2009 to December 2010. A total of 120 specimens were studied by routine paraffin processing and heamatoxylin eosin stain. Detailed histopathological study was done and correlated with age, sex \& clinical presentation. Out of 120 cases, non-neoplastic lesions accounted for $83.33 \%$ and included thyroglossal duct cyst $(2.5 \%)$, Hashimoto thyroiditis (9.1\%), colloid goitre (29.1\%) \& multinodular goitre (42.5\%). Neoplastic lesions accounted for $16.67 \%$ and consisted of follicular adenoma (12.5\%) as the only benign lesion. Papillary carcinoma $(2.5 \%)$, medullary carcinoma $(0.83 \%)$ and anaplastic carcinoma $(0.83 \%)$ were malignant lesions found.

Conclusion: Thyroid lesions predominantly affects females during $3^{\text {rd }}$ and $4^{\text {th }}$ decades of life and commonly present as neck swelling. Multinodular goitre was the commonest non- neoplastic lesion followed by colloid goitre. Follicular adenoma was the only benign neoplasm seen while papillary, medullary and anaplastic carcinoma were the malignant thyroid neoplasms.
\end{abstract}

Keywords: Thyroid lesions, Non- neoplastic and neoplastic lesions.

\section{Introduction}

Thyroid was discovered as a separate structure in the neck and different from the lymph nodes by Vesalius in 1543 and by Wharton in 1656. Meckel in 1806 correlated thyroid hyperplasia during puberty and pregnancy. ${ }^{1}$ By $19^{\text {th }}$ century different thyroid lesions were described. ${ }^{2}$ Thyroid disorders are next common to pancreatic disorders among endocrine diseases. ${ }^{3}$ Studies in Indian population show around 42 million people suffer from thyroid diseases. Patients recognise swelling in the neck making it easier for early diagnosis and better management. ${ }^{4}$

Fine needle aspiration cytology (FNAC) of thyroid is an easy diagnostic procedure to classify thyroid lesions according to Bethesda system. According to this system categorization into definite types is not possible since capsular, vascular and neuronal invasion cannot be demonstrated on FNAC to diagnose malignant lesions. Hence histopathological examination remains gold standard for diagnosis of thyroid lesions.

Thyroid lesions are common in many regions and hence the study was carried out in the city of Bagalkot, WHO classification $2^{\text {nd }}$ edition 1988 formed the basis of classifying thyroid neoplasms in this study. Classifying thyroid lesions histomorphologically helps clinicians to decide further course of management i.e surgical intervention or medical line of treatment.

\section{Materials and Methods}

Study was carried for the period of two years i.e from January 2009 to December 2010. 120 thyroid specimens were received which were formalin fixed, paraffin embedded and 4 microns sections were stained with heamatoxylin and eosin. The slides were analysed taking into account all clinical details, gross and microscopic features.

\section{Results}

120 specimens in total were studied. Female preponderance $(89.2 \%)$ was noted. Commonest age group affected was in 20-40 years (Table 1). The youngest was 8 years old and the oldest patients affected was 76 years.

Clinically 95\% patients presented with neck swelling while 4 patients had dysphagia and 1 presented with dysphonia.

Thyroidectomy specimens were analysed on morphological basis which showed $83.33 \%$ as nonneoplastic and $16.67 \%$ as neoplastic lesions. Analysis of non- neoplastic lesions (Table 2) showed predominance of goitre -86 cases (Fig. 1) of which 51 were multinodular goitre, 35 were simple colloid goitre. The other non- neoplastic lesions were Hashimoto thyroiditis -11 cases (Fig. 2) and thyroglossal cyst -3 cases. 
Analysis of 20 neoplastic lesions (Table 3), benign tumours were more common than carcinoma. Follicular adenoma (Fig. 3) accounted for 15 cases, in which 10 were normofollicular, 3 microfollicular and 2 cases of hurthle cell adenoma. 5 malignant thyroid tumours were seen. Papillary carcinoma (Fig. 4) 3 cases in which 1 was follicular variant type of papillary carcinoma and single cases of anaplastic (Fig. 5) and medullary carcinoma - oncocytic variant (Fig. 6) respectively were seen.
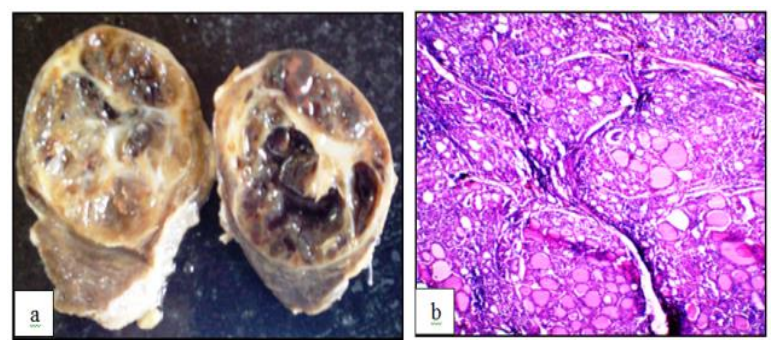

Fig. 1: Multinodular goitre (a) gross: grey white to grey brown capsulated nodule showing variegated appearance. (b) microscopic examination reveals thyroid follicles of varying sizes saperated by areas of fibrosis and haemorrhages
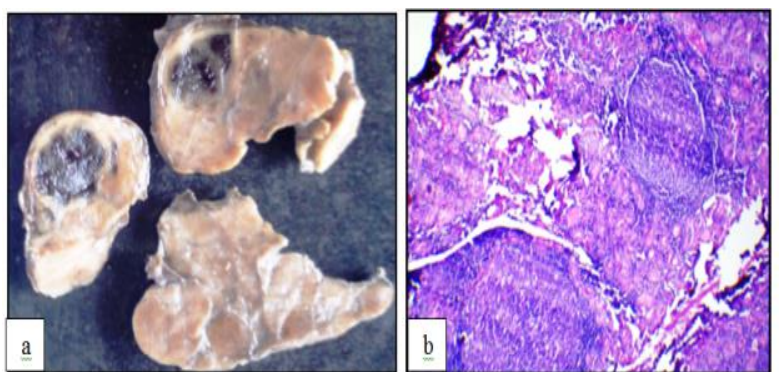

Fig. 2: Hashimoto thyroiditis (a) gross: diffuse grey tan thyroid enlargement with area of haemorrhage (b) microscopic examination reveals extensive lymphocytic infiltrate with lymphoid follicles admixed with atrophic thyroid follicles.
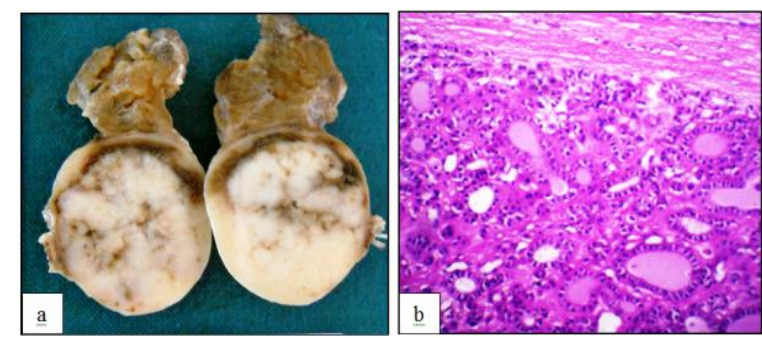

Fig. 3: Follicular adenoma (a) gross: single grey white capsulated nodule (b) microscopic examination reveals closely packed microfollicles with fibrous capsule
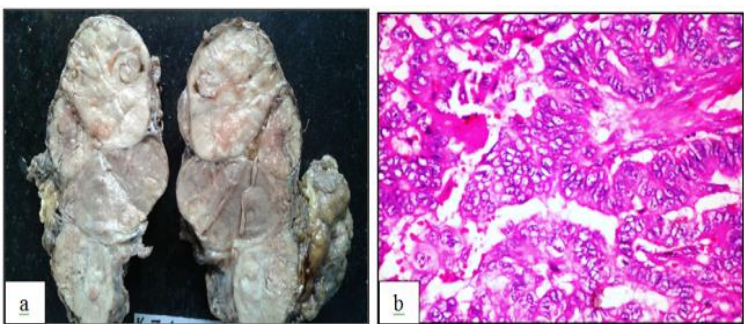

Fig. 4: Papillary carcinoma (a) gross: grey white to grey tan showing papillary nodules and projections (b) microscopic examination reveals papillary projections with fibrovascular core, nuclear overlapping, clearing and grooving
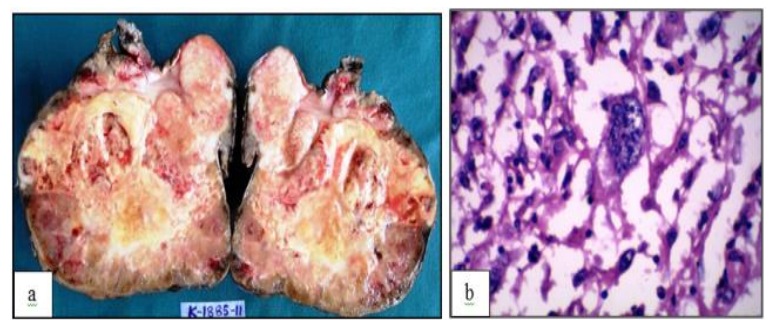

Fig. 5: Anaplastic carcinoma (a) gross: diffuse thyroid involvement, variegated appearance showing solid areas with necrosis and haemorrhage. (b) microscopic examination reveals pleomorphic cells with vesicular nucleus, prominent nucleoli and single bizarre cell can be seen
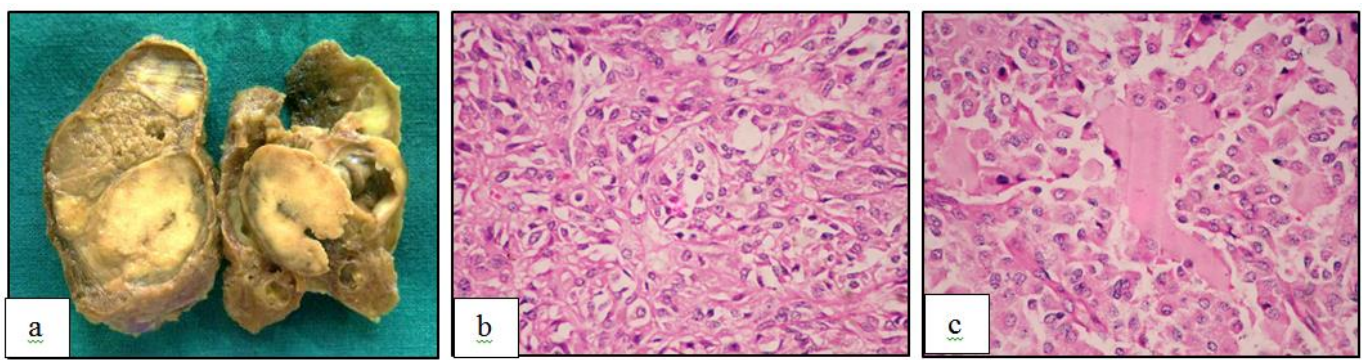

Fig. 6: Medullary carcinoma- oncocytic variant (a) gross: 3 grey white to grey tan, well circumscribed, solid nodular thyroid lesions. (b) microscopic examination reveals polygonal to spindle cells in nests, trabeculae and follicles. (c) polygonal to round oncocytic/ oxyphilic cells showing abundant granular cytoplasm and eccentrically placed nucleus. Stroma shows extracellular amyloid deposits. 
Table 1: Age and Sex distribution

\begin{tabular}{|c|c|c|c|c|}
\hline S.No & Age (Years) & No of cases & Male & Female \\
\hline 1 & $<10$ & 1 & - & 1 \\
\hline 2 & $10-19$ & 7 & 2 & 5 \\
\hline 3 & $20-29$ & 31 & 2 & 29 \\
\hline 4 & $30-39$ & 40 & 5 & 35 \\
\hline 5 & $40-49$ & 20 & 2 & 18 \\
\hline 6 & $50-59$ & 13 & 1 & 12 \\
\hline 7 & $60-69$ & 7 & 1 & 6 \\
\hline 8 & $70-79$ & 1 & - & 1 \\
\hline & Total & 120 & $13(10.8 \%)$ & $107(89.2 \%)$ \\
\hline
\end{tabular}

Table 2: Histomorphological types of non-neoplastic lesions of thyroid

\begin{tabular}{|l|c|c|}
\hline S.No & Types & No of cases (\%) \\
\hline 1 & Thyroglossal duct cyst & $3(2.5 \%)$ \\
\hline 2 & Hashimoto thyroiditis & $11(9.1 \%)$ \\
\hline 3 & Colloid goitre & $35(29.1 \%)$ \\
\hline 4 & Multinodular goitre & $51(42.5 \%)$ \\
\hline & Total & $100(83.33 \%)$ \\
\hline
\end{tabular}

\section{Discussion}

120 thyroidectomy specimens were received during the time period of about 2 years in the department of pathology at Shri Nijalingappa Medical College, Bagalkot, and their histopathological analysis was carried out.

In the present study the commonest age group

Table 3: Histomorphological types of neoplastic lesions of thyroid

\begin{tabular}{|l|c|c|}
\hline S.No & Types & $\begin{array}{c}\text { No of cases } \\
(\mathbf{\%})\end{array}$ \\
\hline 1 & Follicular adenoma & $15(12.5 \%)$ \\
\hline 2 & Papillary carcinoma & $3(2.5 \%)$ \\
\hline 3 & Anaplastic carcinoma & $1(0.83 \%)$ \\
\hline 4 & Medullary carcinoma & $1(0.83 \%)$ \\
\hline \multicolumn{2}{|c|}{ Total } & $20(16.67 \%)$ \\
\hline
\end{tabular}
presenting with thyroid disorders was between $3^{\text {rd }}$ and $4^{\text {th }}$ decades of life while study carried out by Ramesh V $\mathrm{L}$ et $\mathrm{a}^{5}$ found age incidence to be common in $3^{\text {rd }}$ to $5^{\text {th }}$ decades and Jagadale $\mathrm{K}$ et $\mathrm{al}^{6}$ found common age to be $4^{\text {th }}$ to $6^{\text {th }}$ decades. Analysis of sex showed female predominance $(90 \%)$ in Ramesh V L et al ${ }^{5}$ and Jagadale $\mathrm{K}$ et $\mathrm{al}^{6}$ and similar female preponderance of $89.2 \%$ was noted in the present study.

Non- neoplastic lesions in the present study were $83.33 \%$ and neoplastic lesions were $16.67 \%$ which correlated well with Jagadale $\mathrm{K}$ et $\mathrm{al}^{6}$ and Sankran V, while Ramesh VL et al ${ }^{5}$ found $47.5 \%$ of non- neoplastic lesions and $52.5 \%$ of neoplastic lesions (Table 4).

Table 4: Comparison of non- neoplastic and neoplastic lesions of thyroid

\begin{tabular}{|l|c|c|c|c|}
\hline Thyroid lesions & $\begin{array}{c}\text { Sankran V } \\
(\mathbf{n}=\mathbf{1 2 7}) \mathbf{1 9 6 0}\end{array}$ & $\begin{array}{c}\text { Ramesh VL } \\
(\mathbf{n}=\mathbf{1 2 0}) \mathbf{2 0 1 4}\end{array}$ & $\begin{array}{c}\text { Jagadale K } \\
(\mathbf{n}=\mathbf{7 0}) \mathbf{2 0 1 6}\end{array}$ & $\begin{array}{c}\text { Present study } \\
(\mathbf{n = 1 2 0}) \mathbf{2 0 1 6}\end{array}$ \\
\hline Non-neoplastic & $85.8 \%$ & $47.5 \%$ & $71.4 \%$ & $83.33 \%$ \\
\hline Neoplastic & $14.2 \%$ & $52.5 \%$ & $28.6 \%$ & $16.67 \%$ \\
\hline
\end{tabular}

*total number of cases

Comparing the non- neoplastic lesions (Table 5) the present study correlated well with Jagadale $\mathrm{K}$ et al. ${ }^{6}$ Goitre- both simple colloid and multi nodular type were common in the present study probably due to dietery deficiency of iodine. Mulitnodular goitre was the most common non-neoplastic lesion in the present study. There were 51 cases $(42.5 \%)$ with peak age incidence seen between 3rd to 5th decades of life with female preponderence. While in a study conducted by Sankaran $\mathrm{V}^{7}$ and Arora and Gupta $^{8}$ the incidence of multinodular goitre was $18 \%$ and $3.19 \%$ respectively. In this study colloid goitre formed 35 cases $(29.1 \%)$, predominantly in the 3 rd to 5 th decade of life. There was a wide range in the incidence of the colloid goiter reported by several authors. In a study conducted by
Sankaran $\mathrm{V}^{7}$ the incidence of colloid goiter was $36 \%$, the average age being 33 years with female preponderance. In another study conducted by Arora and Gupta ${ }^{8}$ and Meachim and Young ${ }^{9}$ the incidence of colloid goitre were $15.95 \%$ and $49.18 \%$ respectively. Compared to the overall incidence of goitre (all types) in this study 86 cases $(71.66 \%)$, Kilpatrick et $\mathrm{al}^{10}$ reported the overall incidence as $39.4 \%$. Subacute thyroiditis and toxic goitre was noted by Ramesh $\mathrm{V} \mathrm{L}^{5}$ and lymphocytic thyroiditis and ectopic thyroid was noted by Jagadale $\mathrm{K}$ et $\mathrm{al}^{6}$ while present study had no such lesions. The present study accounted for $9.1 \%$ Hashimoto thyroiditis lesions which is relatively high when compared with the study of 94 cases of Arora and Gupta $^{8}$ who found Hashimoto thyroditis as $4.25 \%$ (4 cases) only. Another study conducted by Meachim and 
Young ${ }^{9}$ reviewed 1285 cases and found the percentage of Hashimoto thyroditis as $5.68 \%$ (73 cases), but the present study correlated well with Ramesh $\mathrm{V} \mathrm{L}^{5}$ and
Jagadale $\mathrm{K}$ et $\mathrm{al}^{6}$ showing $9.16 \%$ and $8.57 \%$ respectively.

Table 5: Comparison of various non- neoplastic lesions of thyroid

\begin{tabular}{|l|c|c|c|}
\hline Non neoplastic lesions & $\begin{array}{c}\text { Ramesh VL } \\
(\mathbf{n = 1 2 0}) \mathbf{2 0 1 4}\end{array}$ & $\begin{array}{c}\text { Jagadale K } \\
(\mathbf{n = 7 0 )} \mathbf{2 0 1 6}\end{array}$ & $\begin{array}{c}\text { Present study } \\
(\mathbf{n = 1 2 0}) \mathbf{2 0 1 6}\end{array}$ \\
\hline Colloid goitre & $5.83 \%$ & $21.4 \%$ & $29.1 \%$ \\
\hline Multinodular goitre & $29.16 \%$ & $28.6 \%$ & $42.5 \%$ \\
\hline Hashimoto thyroiditis & $9.16 \%$ & $8.57 \%$ & $9.1 \%$ \\
\hline Thyroglossal duct cyst & $0.83 \%$ & $1.42 \%$ & $2.5 \%$ \\
\hline
\end{tabular}

Analysis of the neoplastic lesions among various studies (Table 6) showed good correlation with Jagadale $\mathrm{K}$ et $\mathrm{al}^{6}$ while Ramesh V L ${ }^{5}$ showed higher

incidence of follicular adenoma and papillary carcinoma.

Table 6: Comparison of various neoplastic lesions of thyroid

\begin{tabular}{|l|c|c|c|}
\hline Neoplastic lesions & $\begin{array}{c}\text { Ramesh VL } \\
(\mathbf{n = 1 2 0 )} \mathbf{2 0 1 4}\end{array}$ & $\begin{array}{c}\text { Jagadale K } \\
(\mathbf{n = 7 0 )} \mathbf{2 0 1 6}\end{array}$ & $\begin{array}{c}\text { Present study } \\
(\mathbf{n = 1 2 0}) \mathbf{2 0 1 6}\end{array}$ \\
\hline Follicular adenoma & $36 \%$ & $7.2 \%$ & $12.5 \%$ \\
\hline Papillary carcinoma & $15 \%$ & $8.7 \%$ & $2.5 \%$ \\
\hline Anaplastic carcinoma & - & $1.42 \%$ & $0.83 \%$ \\
\hline Medullary carcinoma & $0.83 \%$ & $1.42 \%$ & $0.83 \%$ \\
\hline
\end{tabular}

The present study have 15 cases of follicular adenoma, 3 cases of papillary carcinoma, 1 anaplastic carcinoma and 1 medullary carcinoma. Of the 15 cases of follicular adenoma. 10 were normofollicular 3 were microfollicular type and 2 were hurthle cell type. In the present study a 76 year old female presented with dysphonia was diagnosed to have anaplastic carcinoma which is a rare neoplasm of thyroid.

\section{Conclusion}

The present study concluded with the following observations:

1. Female preponderance $-89.2 \%$.

2. Common age group $-3^{\text {rd }}$ to $4^{\text {th }}$ decade.

3. Commonest clinical presentation - neck swelling.

4. Commonest non-neoplastic lesion was goitre - in which $42.5 \%$ were multinodular goitre and $29.1 \%$ were simple colloid goitre.

5. Commonest neoplasm was follicular adenoma$12.5 \%$.

6. Papillary, anaplastic and medullary carcinoma were the malignant tumours found.

The present study highlights the importance of histomorphologiacl typing of thyroid lesions for their better management.

\section{References}

1. Hedinger C, Williams ED, Sobin LH. The WHO classification of Thyroid tumours: A commentary on second edition. Cancer 1989;63:908-911.

2. Alrich EM, Blank RH, Allen MS. Carcinoma of the thyroid. Ann Surg 1955;153:762-67.
3. Gritzmann N, Koischwitz D, Rettenbacher T. Sonography of the thyroid and parathyroid glands. Radiologic clinics of North America, 2000;38(5):1131-45.

4. Unnikrishnan AG, Menon UV. Thyroid disorders in India: An epidemiological perspective. Indian J Endocr Metab 2011;15:S78-81

5. Ramesh VL, Shwetha R. Study of distribution of Thyroid lesionss in a hospital. International Journal of Science \& Research.2014 Dec; 3(12):2441-43.

6. Jagadale K, Srivastava H and Nimbargi R. Recent trends in distribution of thyroid lesions in a tertiary care hospital in India. Ejbps 2016;3(4):234-39.

7. Sankaran V. Swelling of the thyroid. J Ind Med Assoc 1960;34:484-88.

8. Arora HL, Gupta DP. Geographic pathology of thyroid diseases in Rajasthan. J Ind Med Assoc 1967;48:424-28.

9. Meachim G, Young MH. De Quervain's subacute granulomatous thyroiditis: Histologic identification and incidence. J Clin Pathol 1963;16:189-99.

10. Kilpatrick R, Milne JS, Rushbrooke M et al. A survey of thyroid enlargement in two general practices in Great Britain. Brit Med J 1963;29-34. 